\title{
Non-Originalism Differently: the Obligation of the Legislator to Respond to Changing Conditions
}

\section{Introduction}

Non-originalism refers to an approach to the interpretation of the constitution where the text of the constitution adapts to new conditions without any formal change. ${ }^{1}$ This means that the text remains the same, although the result of its interpretation may change over time. ${ }^{2}$ This approach recognizes that a change in the outside world can fundamentally imply a change in the normative content of the constitution. Such new conditions that may influence the interpretation of legislation are, for instance, technological advancement, ${ }^{3}$ the acceptance or introduction of new or different values in society, but also changes in the use of language. ${ }^{4}$

If it is possible for the text of the constitution to be adapted to new conditions, then it is possible that statutes that in the past had complied with the constitution became unconstitutional and, being unconstitutional, were abolished by the Constitutional Court. The abolition of unconstitutional legislation is a constitutional law sanction. ${ }^{5}$ If there is

1 The most fundamental non-originalist argument involves living constitutionalism. The term "living constitution", which indicates development of the constitution due to social conditions but without changing the very text of the constitution. Cf., e.g., D. A. Strauss, Do We Have a Living Constitution?, in: "Drake Law Review" 2011, no. 4, pp. 976-977; C. L. Langford, The Living Constitution: Origins and Rhetorical Implications of the Constitution as Agent, in: "Communication Law Review"2015, no. 1, p. 3. Cf. Related term is also the "evolutionary interpretation” vid. Z. Nový, Evolutionary Interpretation of International Treaties, Den Haag 2017, p. 212.

2 The Czech Republic ranks among countries where the non-originalistic approach is fundamentally permissible. P. Holländer, Ústavní zmèny: mezi neurózou a surrealismem, in: Ústava $\check{C} R$ - vznik, vývoj a perspektiv, ed. P. Mlsna, Prague 2010. The non-originalistic approach was applied by the Constitutional Court, for instance, in its ruling of 26 May 2011, file no. II. ÚS $3241 / 10$.

3 B. Rüthers, Dotvárenen práva soudci, in: "Soudce" 2003, no. 8, p. 5.

4 F. Waismann, Verifiability, in: Logic and Language: First Series, ed. A. G. N. Flew, 1951.

5 J. Filip, Ústavní právo České republiky, Brno 2011, p. 47. 
a sanction, there is also an obligation that should not have been violated. It is an obligation of the legislator to respect the change in conditions and to reflect this situation in existing statutes - to adopt new statutes or amend or abolish existing ones. It is important to add that by the legislator I do not mean one member of Parliament but rather the component of state power. ${ }^{6}$

The obligation to take account of a change in conditions results from the status negativus of the addressees of the rights, ${ }^{7}$ on the basis of which the legislator must refrain from interfering with the fundamental rights of individuals. ${ }^{8}$ If the status negativus means the protection of the rights of individuals, then "refraining from interfering" means both the obligation not to adopt legislation that would interfere with the rights of individuals and the obligation to maintain the existing legislation in such a way that it does not interfere with the rights of individuals. ${ }^{9}$ Refraining from interfering with fundamental rights may therefore also entail the obligation to adopt legislation or amend or abolish the existing legislation. ${ }^{10}$

It would certainly be appropriate for the legislator to always adapt the legislation to changing conditions. However, the legislator does not have the means to be able to even detect all the influences emerging in society and then take them into account. Therefore, he cannot be obliged to respond to any changes in conditions since such an obligation would be unfulfillable. If the legislator does not have to take into account all changes in society, can we say that he has to do so in case of at least some of them? In which cases should the legislator respond to changing conditions and why?

Finding answers to such questions is not only a matter of academic and theoretic interests but also closely related to legal practice. If the abolition of an unconstitutional legal provision is a sanction, we can ask whether such a sanction should include the liability of the legislator (or the state) to compensate for legislative damage. If that sanction included such liability, we would have to outline the limits of the liability to compensate. Or to identify those cases where legislative damage would be compensated. That is precisely where we can find it beneficial to know when the legislator must act and when he does not have to.

6 For more vid. chapter „Who Is the Legislator“.

7 The state activates the status, however, the status belongs to individuals. J. A. Robinson, The Relevance of a Contextualisation of the State-individual Relationship for Child Victims of Armed Confict, in: "Potchfstroom Electronic Law Journal" 2012, no. 2, p. 151.

8 G. Jellinek, Allgemeine Staatslebre, Verlag von Julius Springer, Berlin 1929, p. 419 et seq.

9 R. Alexy, A Theory of Constitutional Rights, Oxford 2002, pp. 166-7.

10 The individual is entitled to such non-interference by the state. However, the entitlement already falls into the status positivus to which the status negativus is necessarily linked. The status positivus represents the right of an individual to enforce their rights against the state with the help of that state. R. Alexy, op. cit., pp. 166-169. 


\section{Method}

To determine the situations in which the legislator may be required to act (to adopt, amend, or abolish a legal regulation), I analysed the judicial decisions of the Constitutional Court of the Czech Republic. ${ }^{11}$ The judicial decisions, however, served only as a useful catalyst for ideas and as an organizational principle of this text. The same conclusions that I came to in this paper can be arrived at even without using Czech judicial decisions. I therefore believe that the results of this paper are applicable not only to the environment of the Czech Republic.

The rulings of the Constitutional Court from which I draw my reasoning relate to gaps in statutes - such gaps that were caused by the negligence of the legislator. In some cases the Constitutional Court described the behaviour of the legislator as an "omission", in other cases as "unconstitutional inactivity". Both omissions and unconstitutional inactivity result in an unconstitutional state. However, in the case of unconstitutional i activity, both the resulting product and the very behaviour of the legislator are unconstitutional. That is the difference between an omission and unconstitutional inactivity.

Every time the Constitutional Court identifies the legislator's behaviour as unconstitutional inactivity, it also points to the indicia (information) based on which the legislator knew or ought to have known that he should adopt, amend, or abolish some legislation. Such indicia are (a) formal sources of law by which the legislator has committed to the adoption of legislation and (b) the Constitutional Court's rulings by which the Constitutional Court drew attention to the existence of a gap in a statute and to the need to adopt new legislation. ${ }^{12}$ On the other hand, in the case of the legislator's omission, the Constitutional Court does not refer to any such indicia. From this, I infer that in the event of an omission the legislator did not have to know about the possible creation of an unconstitutional gap. Therefore, a mere omission is not an unconstitutional act, as the legislator did not have to know that he should act - adopt, amend, or abolish legislation. The legislator acts unconstitutionally only if he knows he must act but chooses to remain inactive. ${ }^{13}$ Such a decision can either be a decision to ignore one particular indicium or to refrain from reflecting on certain types of indicia at all. If the legislator decides to be inactive, then he deliberately ${ }^{14}$ creates an unconstitutional gap in a statute..$^{15}$

11 In this text, I will continue to refer to the Constitutional Court of the Czech Republic.

12 Vid. e.g., the ruling of the Constitutional Court of 28 March 2006, file no. ÚS 42/03.

13 The very decision to ignore indices is an act. Cf. O. Weinbeger, Alternative Handlungstheorie, Wien-Köln-Weimar 1996, p. 107. Omission, unlike unconstitutional inactivity, is not a decision - it is not a kind of action. O. Weinberger, Norm und Institution. Eine Einführung in die Theorie dews Rechts, Wien, 1988, pp. 146-147.

14 Or consciously. Cf. O. Weinberg, op. cit., p. 83.

15 The legislator is bound by his own statute (G. Jellinek, op. cit., p. 367 et seq.). If the legislator deliberately or knowingly leaves an unconstitutional provision or an unconstitutional gap, then his very behaviour is unconstitutional because he violates his own statute. The prohibition of 
It cannot be determined with certainty what the legislator actually knows or does not know. Why is this so will be explained in the following sections. If, however, it is possible to set a boundary for the knowledge of legislator, then it is a border that only determines what the legislator must know and what the legislator does not have to know. Let us therefore consider the legislator's knowledge in only two categories. The first are the cases when the legislator must know, the second are those when the legislator does not have to know. ${ }^{16}$

In the following text, I will analyse the specificities of the unconstitutional inactivity of the legislator. In individual sections, I will gradually analyse cases in which the legislator did not respond to indicia in the form of (a) formal sources of law by which he committed to adopt a statute and (b) rulings of the Constitutional Court by which the Court drew attention to the need to adopt certain legislation. By analysing these two groups of cases, I will pursue two purposes. First, I will explain why the legislator should follow and respond to such indicia and, second, examine the characteristics of unconstitutional inactivity of the legislator. Subsequently in the final section, this will allow me to define when and why the legislator must respond to changing conditions in society.

\section{The Formal Sources of Law}

The unconstitutional inactivity is committed by the legislator if he ignores the formal sources of law by which he committed himself to adopt a statute. Why the legislator should respond in such a case is quite obvious. If the state is governed by the rule of law, then the state is bound by its own law. To the legislator, as a component of state power, applies the same as to the state itself, ${ }^{17}$ i.e., he is bound by his own statute and must fulfil what he has committed to.

The issue is a little more interesting if we look at specific cases in which the Constitutional Court described the legislator as unconstitutionally inactive. There were basically two types of such situations: either (1) the legislator referred to a non-existing statute which was supposed to be adopted soon, but which had not been adopted yet;

knowingly or deliberately violating own statute results from the rule of law. Cf. D. Patterson, A Companion to Philosophy of Law and Legal Theory (2nd edition), Singapore 2010, pp. 666-667.

16 Since we do not know what the legislator actually knows or does not know, it is not useful to think about the categories of cases where the legislator would have to know something but did not or, vice versa, when the legislator knows something though he did not have to.

17 Cf. J. Fairlie, The Separation of Powers, in: "Michigan Law Review" 1923, no. 4., p. 413. See also the ruling of the Constitutional Court of 28 April 2009, file no. P1. ÚS 27/09. 
or (2) the adoption of particular legislation was prescribed by a EU directive ${ }^{18}$ but the legislation was not adopted.

One could also argue that there is a third situation and argue as follows: under the Constitution, the legislator implicitly committed to maintain the legal order in a form which conformed with the constitution. Therefore, it would always be the case that when the legislator leaves an unconstitutional statue, provision, or gap in statute, he commits unconstitutional inactivity. This argumentation, nevertheless, would be wrong. This is because in these cases it would be a mere omission on the part of the legislator, not unconstitutional inactivity. In order for the legislator to commit unconstitutional inactivity, both the result and the very behaviour of the legislator must be unconstitutional.

The legal order is a complex system and its individual components - statutes - are adopted pro futuro. Therefore, at the time they are adopted, the situation under which they will be applied is unknown, while constant checking of the constitutionality of all the statues and possible gaps in them is not realistically feasible. ${ }^{19}$ Thus, it is not possible to ensure that each individual legal provision and its individual parts are always in compliance with the constitution. The legislator cannot be aware of all unconstitutional elements in the legal order, and so we cannot require him to fulfil the unfulfillable task of correcting every such unconstitutionality. We can only require that the legislator rectifies those defects of which he had to know. Only if the legislator had to know about the unconstitutionality in the legal order and yet did not interfere, then he violated his duty and committed unconstitutional inactivity. Such a claim raises questions: What does it mean that the legislator has to know something? And why should the legislator know about unconstitutional gaps in the cases when (1) he himself referred to a non-existent statute in legislation or (2) when the adoption of a specific legal regulation was imposed by a EU directive; yet, in contrast, he did not have to know about unconstitutionality in other cases?

\section{Who Is the Legislator?}

In order to define what the legislator should know or not, first we must define who the legislator is and what his will and actions are.

The will of the legislator is shaped by the wills of the individuals who are members of

Parliament, however, neither them nor the Parliament as a whole are the legislator. The

18 The legislator transferred part of his competences to the European Union in accordance with Section 10a of Act no. 1/1993 Coll, the Constitution of the Czech Republic, as amended. If the legislator is bound by a EU directive, such an obligation can then be considered as the legislator's own.

19 Especially, axiological gaps in statutes are very difficult to detect. For axiological gaps, for example: A. Peczenik, On Law and Reason, Dordrecht 2009, p. 20. 
legislator is one component of state power. The wills of the members of the legislative body and their behaviour are a necessary component of the legislator's will and actions. ${ }^{20}$ If the members of the legislative body have no will or take no actions, it would not be possible for the legislator to have any will or take any action. However, the will of the legislator is not a mere aggregate of the wills of the members of the legislative body. Also, the actions of the legislator do not take place at the same time and in the same manner as the actions of those individuals. The will of the legislator is original and distinct from the wills of the members of the legislative body, and so are his actions.

The legislator has the legislative will - to create and issue statutes and to form the purpose of these statutes. The purpose of each statute is, in addition to ensuring the legal certainty of its addressees, the fulfilment of a certain concept of general prosperity and justice. ${ }^{21}$ The legislator's will is thus that statutes ensure general prosperity and justice. Can we say the same about the wills of the individuals who are members of the legislative body? How would we explain where the will of the legislator came from if the will of every single member of the legislative body was to adopt a statute with different concepts of general prosperity and justice? ${ }^{22}$ The legislator's will cannot be obtained as the sum or average of the wills of the members of the legislative body, and yet the legislator would have to have some will to be directed towards a certain concept of general prosperity and justice. ${ }^{23}$ The content of the legislator's will may be different from that of the members of the legislative body.

Even more marked would be an extreme case where the wills of the members of the legislative body would not be directed towards general prosperity and justice at all but rather at their own personal benefits. Then the will of the legislator could not be the same as the wills of such individuals. The will of the legislator cannot coincide with wills of these individuals who pursue personal gain. It must lack something compared to the wills of those individuals - that pursuit of personal gain. On the other hand, it must

20 If it would not matter who sits in the Parliament, we might not be able to explain where proposals for changes in the legal order of a certain direction come from.

21 G. Radbruch, Der Mensch im Recht: ausgewählte Vorträge und Aufsätze über Grundfragen des Rechts (3rd edition), Göttingen 1957, pp. 88 et seq.

22 See also: R. Dworkin, Law's Empire (3rd edition), London 1991, p. 313 et seq., especially p. 440; R. Ekins, The nature of legislative intent, Oxford, 2012, p. 29; R. D. Doerfler., Who Cares How Congress Really Works?, in: "Duke Law Journal" 2017, no. 5, pp. 998 et seq.

23 J. McGarry, Intention, Supremacy and Judicial Review, in: "The Theory and Practice of Legislation" 2013, no. 2, p. 266. Also, members of the legislative body do not even have to have general prosperity on mind when voting but their own benefits, which however cannot be the content of the will of the legislator. Despite, the legislator's will aims towards some form of general prosperity even though it does not stem from the will of either of the members of the legislative body. Cf. R. Ekins, op. cit., s. 233; R. Dworkin, A Matter of Principlee, Cambridge 1985, p. 38. 
be broader than the wills of the individuals, i.e., it must contain some concept of general prosperity and justice that wills of the individuals does not. ${ }^{24}$

The wills of the individuals is a constructive element of the will of the legislator, however, the will of the legislator is comprised of more than that. The will of the legislator may be much broader in relation to the wills of the individuals and also contain such content that the wills of the individuals did not contain at all. In another sense, the will of the legislator may be much narrower than the wills of the individuals and lack many of the intentions and purposes that wills of the individuals contain. However, even if all these individuals pursued general prosperity and justice and agreed on a specific conception of these purposes, it would not be possible to say that the will of the legislator was identical with their will or with the sum or average of their wills. If, for example, the legislator adopts a statute with which the individuals who are members of the legislative body later disagree, that statute is not abolished at the moment of such disagreement. It will only happen if the legislator takes formal or official steps that eventually abolish the statute. The will of the legislator does not change at the moment of change in the wills of these individuals, but only later if the formal procedure is completed. ${ }^{25}$

Similarly, neither are the legislator's actions identical with those of the members of the legislative body. Members of the legislative body act if they vote for a specific bill. On the other hand, the legislator acts only after all the steps necessary for the adoption of a statute have been taken, i.e., upon the validity of the given statute. Thus, the legislator's activity or inactivity cannot be identified on the basis of the activity or inactivity of the members of the legislative body but only on the basis of an empirical finding regarding the existence or non-existence of the legislation.

To determine what is or is not the legislator's action and when it takes place, the legislator creates a standing intention. ${ }^{26}$ The standing intention is the way how to determine what statues and with what content will be adopted and how they will be adopted. ${ }^{27}$ This includes both the procedure enshrined in constitutional statutes and informal political culture and the institutionalized practices of the creation of statutes, ${ }^{28}$ which co-determine the form of the resulting statutes. The standing intention sets out a series of control steps to ensure the rational and coherent decision-making of the legislator. ${ }^{29}$ The legislator acts only after the fulfilment of all the steps determined by the standing intention.

24 Members of the legislative body do not even need to know what they vote for. S. J. Shapiro Legality, London 2011, p. 72.

25 Similarly, neither the legislator's actions are identical with those of the members of the legislative body - but also neither with one chamber of the Parliament. Cf.J. McGarry, op. cit., p. 267.

26 Vid. R. Ekins, op. cit., pp. 58 and 223, 224.

27 Ibidem, p. 58.

28 Cf. K. Bayme, Parliamentary Democracy. Democratization, Destabilization, Reconsolidation, 1789-1999, Basingstoke 2000, p. 104.

29 R. Ekins, op. cit., p. 219. 


\section{What Does the Legislator Have to Know?}

What does it mean that the legislator has to know something? The will of the legislator is perhaps original, yet it is not a transcendental element that arises of its own accord. The will of the legislator is created through a complicated and sophisticated process the standing intention - which is a human creation. The very will of the legislator is then also a human creation, as well as all the legislator's possibilities and abilities to know something. The form of the standing intention is therefore decisive for defining what information the legislator has to know.

Although humanity currently has access to computing technology that may be helpful in identifying and analysing information to design better statutes, it has not been used to this end much, since the standing intention does not prescribe the use of computing. ${ }^{30}$ Reflections on what particular statutes should be like thus take place mainly in human minds. Therefore, we cannot assume that the legislator possesses all possible knowledge available to mankind but at most only that objectively available to the people who are involved in the legislative process in a particular country. Who are the people whose knowledge can be used to determine the legislator's knowledge?

In a developed democratic state, the legislative process involves different people. They are the members of the legislative body, and also the head of state (if he approves bills). And also officials who write the text of bills, since based on the theory of pacts with the adoption of a bill the ideas and considerations upon which these officials created the text are also adopted. ${ }^{31}$ It should also be remembered that the legislative process does not end with the adoption of a bill. It is a continuous activity involving not only the creation of statutes but also the management of the existing legal order. The legislator not only has the information that existed at the time of creating the statute available but also gains new information that appears later on. Therefore, the legislator also has access to information possessed by those involved in the legislative process after the adoption of the statute. Of course, we can never ascertain the true knowledge of all these persons. If we think about the possibilities of their knowledge, then we mean such information that they could objectively know. These possibilities define the maximum limits of knowledge that we can assume that the legislator has.

The question of where the minimum boundary of what the legislator must know lies will be discussed in the following sections. For the time being, let us remain with the claim that the legislator must know as much as can be expected of those involved in the legislative process. In many countries, these individuals make a vow before commencing their mandate, office, or position. In the Czech Republic, such a vow is made by MPs, senators, and the President, who all swear to act "[...] to the best of their knowl-

30 At least not in most countries including, for example, the Czech Republic.

31 See Paktentheorie: F. Bydlinski, Grundzüge der juristischen Methodenlehre, Wien 2003, p. 23. 
edge and conscience". ${ }^{32}$ Officials involved in writing bills then swear to fulfil their duties in a proper, conscientious, and professional manner. ${ }^{33}$ Part of the standing intention that defines the process of making a statute is the performance of functions and duties in accordance with such vows. Since the legislator's knowledge depends on the possibilities of the persons involved in the legislative process, it can be expected of the legislator to possess at least basic knowledge of the status of the legal order and its needs.

Information about whether or not an unconstitutional provision or a gap was created or is being created in the legal order may not be sufficiently obvious for individuals. So we could not expect them to know of such a situation. Therefore, we cannot claim that the legislator had to know about it. If the legislator did not have to know about an instance of unconstitutionality in the legal order, then he did not commit an unconstitutional inactivity but just made an omission. On the other hand, when the legislator explicitly committed to the adoption of some legislation, for example by reference in another statute or in directive, then such information about such an obligation was objectively available to the individuals involved in the process of creating statutes. These persons thus had to be familiar with that information, if they conducted their duties professionally and to the best of their conscience and knowledge. The information was thus present in the process of preparing and adopting statutes determined by the standing intent, and the legislator therefore knew the information. If the legislator did not respond and thus did not adopt, amend, or abolish the legislation despite the foregoing, then he committed unconstitutional inactivity.

\section{The Rulings of the Constitutional Court}

According to the judgements of the Constitutional Court of the Czech Republic, the legislator commits unconstitutional inactivity if he does not respond to a ruling in which the Constitutional Court drew attention to a gap in a statute or to the need to adopt or amend legislation. But why should the legislator follow the rulings of the Constitutional Court? ${ }^{34}$

Let us follow the thesis that the legislator creates statutes but also that statutes are not law but only a source of law. ${ }^{35}$ The purpose of a statute is to regulate social situations and

32 Section 23, § 3 and Section 59, § 2 of Constitutional Act no. 1/1993 Coll., the Constitution of the Czech Republic.

33 Section 32, paragraph 2 of Act no. 234/2014 Coll., on Civil Service.

34 For more about the possibility of the binding effect of ruling of the Czech Constitutional Court vid. J. A. Gealfow, Case Law and its Binding Effect in the System of Formal Sources of Law, in: "The Journal of the University of Latvia. Law", no. 11 (in print).

35 J. C. Gray, The Nature and Sources of the Law, New York 1909, pp. 111, 115; N. MacCormick, Institutions of Law. An Essay in Legal Theory, Oxford 2007, p. 57. 
relationships. ${ }^{36}$ The statute thus appeals to its addressees and everything serves to give them clear messages - so that it is understood by such addressees. Without the addressees to receive, interpret and apply the message, law would not exist and a statute would be just a plain text. Statutes only become law through the process of interpretation and application. ${ }^{37}$

Statuses are addressed to different entities and so different entities interpret and apply them, but in principle we can divide them into two categories. On the one hand, it is the executive and judicial authorities (let us call them "public authorities"), and on the other hand, there are the addressees of public power who apply statutes in their own actions. Of these two groups, it is public authorities which, through their activities - through interpretation and application of statutes - participate in the creation of law. It is true that the creator of law is the state, and therefore law may be formed only within public power. Thus, a subject who does not exercise public power cannot participate in the creation of law. ${ }^{38}$

\section{The Creation of Law}

Let us start with the claim that any text, i.e., also the text of a statute, "is interwoven with the unspoken. The unspoken means that which is not manifested on the surfaceat the expression level. However, it is the unspoken that must be updated at the level of content. In this respect, the text, much more decisively than any other message, requires of the reader active and conscious cooperative actions". ${ }^{39}$ The transfer of information between the legislator and public authorities is communication. It is a communication since it requires an active approach both on the part of the legislator, who creates thestatute, and on the part of public authorities, who receive and interpret the message. Let me remind you that this is not about communication between persons. The legislator is not a physical person, and neither are public authorities. The way in which the legislator expresses his will is given by the standing intent, and his only mean of communication is a statute.

Knowing that the interpreter is active and he himself gives meaning to the text is part of the generative mechanism of the text on the part of the legislator. "Generating the text means implementing a strategy which also contains predictions of the moves of others -

36 T. Hobbes, Leviathan, Cambridge 1996, p. 89.

37 J. C. Gray, op. cit., p. 115.

38 The resulting law can then be influenced by the legislator by adopting other statutes.

39 U. Eco, Lecotor in fabula, Prague 2010, p. 66. 
as is the case in every strategy." ${ }^{40}$ Because the meaning of the message is also determined by the context, ${ }^{41}$ it is the context the legislator uses in his strategy.

Context is the actual or anticipated knowledge shared by the participants of communication, ${ }^{42}$ i.e., the legislator and public authorities, and it is established through their mutual long-term discourse. Context is, for example, language, grammatical rules, but also professional terms or interpretative methods. The legislator assumes the interpreter's knowledge and at the same time creates $i^{43}$ by means of constructing legal texts, systematics, references, use of terms, but also the matter and value orientation of statutes. ${ }^{44}$ Thus, the legislator creates the reader's competence to understand the message conveyed by statutes. However, communication is not one-way. The context is created and defined by public authorities by using specific interpretative methods and by specifying terms and meanings for particular applications. ${ }^{45}$

In the creation of a legal text, the legislator takes knowledge of the context for granted and assumes that the legal text will be understood. For example, the legislator does not explain the grammatical or interpretative rules and only assumes that the interpreter is already familiar with them and applies them. Public authorities also regard the context as given and use it automatically to interpret statutes even though the text of the statutes itself does not instruct them to do so. They assume that the legislator wrote the statute with the intent to use the context in its interpretation.

Such automated application of the context has certain benefits for the legislator. The legislator's task to communicate a message is thus easier. By knowing the shared context, the legislator can anticipate interpretative procedures and adopt the appropriate strategy to express his will as clearly as possible. However, the existence of shared context is not only an advantage but also an obligation. As public authorities use the context for interpretation automatically, the legislator must take such application of the context into account and adapt his text-writing strategy accordingly, otherwise the message may not be comprehensible. ${ }^{46}$

40 Ibidem, p. 69.

41 R. C. Stalnaker, Context and Content, Oxford 1999, p. 65; Ekins, op. cit., p. 209.

42 Ibidem, p. 67; Cf. also U. Eco, op. cit., p. 72.

43 Cf. U. Eco, op. cit., p. 72. Identical citation idem, The role of the Reader. Explorations in the Semiotics of Texts, Bloomington 1984, p. 7.

44 In addition to adopting statutes, the legislator makes value decisions through choosing the content of statutes. The body of statutes, adopted perhaps even across many election terms of the Parliament, then forms the legislative intent. For more about the legislative intent, vid. footnote no. 51 .

45 Cf. J. F. Manning, The Absurdity Doctrine, in: “Harvard Law Review” 2003, no. 8, p. 2465.

46 Incomprehensibility of legal texts is noted by Lon L. Fuller as one of eight reasons that lead not only to a poor system of law but to something that is not law at all. L. L. Fuller, Morality of Law (revised edition), London 1969, pp. 33 et seq. 


\section{Statute and Law}

One of the main functions of legislation is the legislative function. ${ }^{47}$ This does not mean, however, that the legislator simply has to adopt some statutes. Statutes are not the purpose in themselves, they are a means of fulfilling the purpose of organizing and directing society. Statutes, as mere means, must correspond to their purpose and fulfil it. ${ }^{48}$ They must form a coherent and functional whole - only in that case can they serve to organize and direct society. ${ }^{49}$ If the legislator adopts a new statute, that statute will join a body of already existing statutes that have been interpreted and applied in some way. This means that they had already served to define what law is. New statutes thus enter the legal environment, and if they are to be consistent with it, they must be interpreted with respect to it. Existing law is thus a shared context of communication. In choosing a statute making strategy, the legislator has to take account of the existence of the body of law and to adapt the text of new statute accordingly. ${ }^{50}$ Similarly, public authorities must use the existing law as a context when interpreting statute.

Certainly, the legislator cannot be familiar with the decisions, rulings, and resolutions of all the courts, or even the acts of all administrative authorities. The knowledge of the legislator is limited by the possibilities of the individuals who are involved in the creation of statutes. The legislator is thus not obligated to be familiar with all existing law as a context. Therefore, even if the legislator adopts a statute that does not comply with law, his behaviour may not necessarily be an unconstitutional action, but merely an omission. Behaviour is only unconstitutional when the legislator had to have known he was violating law.

The legislator does not need to be familiar with the whole context, i.e., with decisions of all public authorities. I do not intend to draw a line in this respect, separating all of those decisions the legislator must know. I will confine myself to stating that it can at least be said with certainty that the legislator must know the rulings of the Constitutional Court. The Constitutional Court is the guarantor of democracy and human rights. If the Constitutional Court rules that a certain matter needs to be regulated by statute, ${ }^{51}$

47 Vid. Bayme, op. cit., p. 72 et seq.

48 Adoption of a statute that does not have a rational link to its purpose or that is unable to achieve its purpose is arbitrariness on the part of the legislator. Viz ruling of the Constitutional Court of 19 January 2005, file no. P1. ÚS 10/03; Ruling of the Constitutional Court of 12 March 2008, file no. P1. ÚS P1. ÚS 83/06.

49 The existence of mutually contradictory rules and the inability to reach compliance between the declared rules and their application in practice leads not only to a poor system of law but also to something that is not law at all. L. L. Fuller, op. cit., pp. 33 et seq.

50 Adapt so that (1) the message carried by the statute is comprehensible for the interpreter and (2) the desired outcome of the interpretation is capable of forming, along with the existing body of law, a coherent meaningful and functional whole.

51 In addition to adopting statutes, the legislator makes value decisions through choosing the content of statutes, by which he creates the legislative intent. The legislative intent is a trend of 
then the legislator knows that he has to act and adopt the statute. If the legislator remains inactive instead, it is unconstitutional inactivity.

Law is created not only by the legislator. It is created both by the action of the legislator who codes the message into the text of the statute and the action of public authorities which interpret and apply the texts of statutes. It is useful not to concentrate the creation of law into the hands of only one entity, but rather to distribute this activity among multiple entities. If there are two different entities fulfilling two different tasks ${ }^{52}$ who have the control over the form of law, better law can be expected. ${ }^{53}$ "If statutes were enforced by the subject who issue them, such subject would not have the motivation to create them free of errors because he could relatively easily 'repair' them later during their application process. ${ }^{54}$ If the legislator is relying on the interpreter, he must be careful and choose such strategies to ensure that the interpreter understood. Moreover, thanks to this statutes are more accessible to other addressees of statutes who also have to interpret and follow them. The publicly available interpretative conclusions of public authorities thus also serve, among other things, to other addressees of statutes as guidance for their interpretation.

\section{The Addressees of Public Power}

Public authorities are not the sole interpreters. There are also other subjects - let us call them the addressees of public power - who interpret statutes. However, although they

value decisions, and it should be followed by other newly adopted statutes (F. Melzer, Metodologie nalézáni práva. Úvod do právni argumentace, Prague 2009, p. 221). The overall content of the legislative intent cannot be determined with certainty as there is no one with such competence to formulate the entire content of the intent. The legislator does not comment on his decisions - he communicates only through legal texts. However, we cannot give up on determining the content of the legislative intent. That is because the legislative intent serves also to assess the constitutionality of statutes and actions of the legislator. Although the legislative intent cannot be determined in its entirety, there are entities that define at least parts of the legislative intent - public authorities. The outcome of the application of a statute must be in line with the legislative intent. In order to be able to proceed in this manner, public authorities must first of all define the part of the legislative intent that applies to their case and then interpret a specific statute (the one that is to be applied) in accordance with the defined legislative intent. Public authorities thus define the legislative intent, i.e., they define what is lawful.

52 The legislator adopts the general rules pro futuro, and public authorities test them, specifying and eventually completing interpretations and applications in practice. For the distinction in tasks, functions, and limitations of the legislator, on the one hand, and of public authorities, on the other hand, vid. also R. Dworkin, Taking Rights Seriously (3rd edition), Cambridge 1977, pp. 112 et seq.; R. Ekins, op. cit., p. 81.

53 The sovereignty of the legislator is not threatened by such a division of functions because the suverenity of legislator lies in the monopoly over the creation of statutes. A. V. Dicey, Introduction To The Study Of The Law Of The Constitution, Indianapolis 1982, pp. 37 et seq.

54 M. Hapla, Délba moci a nezávislost justice, Brno 2017, p. 23. 
also interpret statutes, they do not define what law is, as is the case of public authorities. ${ }^{55}$ However, it is the addressees of public power who are the reason for the existence of a substantial part of the statutes. Statues are directed towards them in the first place because the main purpose of the existence of law is the regulation of their social relationships. ${ }^{56}$ Therefore, the addressees of public power cannot be left out of the process of making law.

The legislator also communicates with the addressees of public power, and does so through the same statutes used for the communication with public authorities. In the communication of the legislator with the addressees of public power, the legislator also turns to the context and relies on its use by the addressees of public power in interpretation. However, the context in this case is a relatively limited piece of information that such persons could know. ${ }^{57}$ The fact that the legislator has to take account of the possible knowledge of the addressees of public power is the context in the communication between the legislator and public authorities. In other words, the fact that one communication (between the legislator and the addressees of public power) has a certain context is the context of another communication (communication between the legislator and public authorities).

Furthermore, if law is not a self-serving element but rather exists because of the addressees of public power and in order to manage their social relationships, then the addressees of public power and their social relationships themselves are the context of law-making. They are the context of the communication between the makers of law, i.e., the legislator and public authorities. The existence of the addressees of public power and the existence of their social relationships must be taken into account by the legislator and public authorities in their communication. The law that is created must fulfil the purpose of its existence, i.e., to regulate the social relationships of the addressees of public power. ${ }^{58}$

The legislator therefore has to adopt such strategy of creating statutes that takes the addressees of public power into account. The public authorities must approach the interpretation of statutes in the same sense. ${ }^{59}$ However, a strategy for creating statutes, as any other strategy, may be disturbed by randomness, ${ }^{60}$ especially in the form of changes in social conditions. Therefore, the legislator, like any other strategist, has to consider randomness. The legislator can either anticipate social developments or, if that is not

55 For the reason, vid. Chapter "Rulings of the Constitutional Court".

56 T. Hobbes, op. cit., p. 89.

57 R. D. Doerfler, op. cit., p. 1032.

58 Purposeless law is arbitrary law. See footnote no. 48.

59 In interpreting statutes, public authorities are not always obliged to decipher the message the legislator intended. In interpreting, it is more important that the result is coherent with the body of existing law and fulfils the purpose of the statute. See subchapter "Statute and Law". 60 U. Eco, op. cit., p. 70. 
possible, expect that statutes may be interpreted differently under potentially changed circumstances.

Why is it possible for statutes to be interpreted differently in the light of changing social conditions? Changing conditions means changing the context in which public authorities will interpret statutes. Thus, public authorities will apply teleological interpretation, to which (according to interpretative rules) public authorities should give priority over the method of historical interpretation. ${ }^{61}$ Interpretative rules are themselves part of the shared knowledge of the legislator and public authorities, thus also they are the context. The legislator must therefore know that the teleological interpretation will be preferred.

Moreover, not taking the current situation into account when interpreting statutes would mean not taking the addressees of public power into consideration. The legislator and the addressees of public power communicate with each other through statutes. Their communication does not take place at the moment when the statute is adopted, but at any time while the statute is valid, whenever any of the addressees of public power interprets the statute for their own purposes. The context of such communication will be the current social situation, not the historical situation in which the statute was adopted. Knowledge of the historical situation at the time the statute was adopted cannot be expected of the addressees of public power. An incidental restriction and failure to take into account the resources that the addressees of public power have available in the interpretation of the statute would create a certain "democratic gap". ${ }^{2}$ In the end, if the change in social conditions were not taken into account when interpreting the statute, it might be that the statute required something impossible from its addressees. ${ }^{63}$

Unlike the legislator, public authorities act on their share law making at the time when they know the concrete context - the current conditions. On the other hand, the legislator adopts statutes pro futuro, and it is his job to deal with potential changes in society. The possibility of relying on the context, i.e., on the interpretation of statutes in the light of changed conditions, is a strategic advantage for the legislator. Thanks to this, some statutes can be adapted to new realities and continue to cover and govern social relationships without having been formally amended. However, a change in conditions is also an obligation for the legislator. The legislator must maintain the legal order in such a way that it still meets its purpose, i.e., to regulate social relationships. However, as a result of such changes, legislation of higher legal force can be interpreted in a different way and the existing statutes then could no longer be interpreted as conforming with

61 Which on the contrary works with the conditions existing at the time of adoption of the statute.

62 R. D. Doerfler, 2017, op. cit., p. 1041.

63 If law requires something impossible, then it is not only bad law but not law at all. L. L. Fuller, op. cit., pp. 33 et seq. 
the legislation of higher legal force. In other words, the existing statutes could no longer sufficiently regulate social relationships ${ }^{64}$ or they would begin to interfere with the rights of individuals as a result of the change. ${ }^{65}$ In such a case, the legislator has an obligation to intervene and adopt, amend, or abolish the legislation.

\section{Unconstitutional Inactivity}

The difference between omission and unconstitutional inactivity lies in the possibilities of the legislator and his obligations to detect an arising unconstitutional situation in the legal order. Unconstitutional inactivity is committed by the legislator when he has to know that the unconstitutional situation is arising in the legal system but fails to adopt, amend, or abolish the respective legislation.

The legislator's knowledge is derived from the possible knowledge of the individuals who are involved in creation of statutes. Therefore, it cannot be argued that the legislator always commits an unconstitutional inactivity if an unconstitutional gap in a statute is created or if a legal provision becomes unconstitutional. The emergence of any such unconstitutional situation might not be sufficiently evident to say that the individuals who are involved in the creation of statutes should have known or even had to have known about it. In other words, the legislator does not have to know about the emergence of all the unconstitutional situations caused by changing conditions. How to define those situations about which the legislator has to know and to which he has to respond?

The legislative process does not end with the adoption of a specific statute. It is a continuous activity involving not only the creation of statutes but also the management of the existing legal order. The legislator has access not only to the information that existed at the time the statute was created but he also gains new information that emerges later. Based on the obligation to nurture the legal order, the legislator has to analyse the legal order and its problems at certain time intervals, ${ }^{66}$ and this is exactly the way the legislator should identify its shortcomings. The legislator should reflect on at least those changes in conditions that are serious, pressing, or fundamental and that bring about significant and obvious economic, social, and technological changes. ${ }^{67}$ In other words, such changes

64 The provisions of statutes can no longer be interpreted in such a way so as to comply with the Constitution.

65 See the status negativus, according to which the legislator should refrain from interfering with individuals' rights. As a result of changes in society, statutes may also stop complying with the legislative intent which is the trend of value decisions made by the legislator and with which statutes must comply (vid. footnote no. 51).

66 Cf., e.g., O. Weinberger, 1988, op. cit., pp. 212-213.

67 For example, the emergence of completely new communication technologies, such as fax or the Internet. B. Rüthers, 2003, op. cit. p. 5. 
that are obvious to the individuals who are involved in creation of statutes, and who have to do so professionally ${ }^{68}$ and to the best of their knowledge and conscience. ${ }^{69}$ Sufficiently obvious are at least those phenomena, facts, and conditions about which there is a society-wide ${ }^{70}$ debate, or at least wide-ranging professional debate. ${ }^{71}$

If the maximum limit of knowledge of what we can expect of the legislator is the boundary of human possibilities, then the minimum limit is the knowledge of the context of lawmaking. At least those elements of the context that are obvious to the individuals who carry out their tasks in the creation of statutes professionally and to the best of their conscience.

\section{Conclusion}

Non-originalism refers to an approach to the interpretation of the constitution where the text of the constitution adapts to new conditions without any formal change. This approach recognizes that a change in the outside world can imply a change in the normative content of the constitution. If the content of the constitution is changed in such a way, it may happen that some statutes become unconstitutional or that an unconstitutional gap in a statute may arise. In such a case, the legislator should, if such changes result in interference in the rights of individuals, adopt, amend, or abolish the legislation. The legislator certainly does not have to respond to all the changes in conditions, however, he has to respond to those about which he knows. If not, the legislator consciously interferes with the rights of individuals and his very behaviour - inactivity - is unconstitutional.

To determine the requirements of the legislative process, the legislator creates the socalled standing intent, which is a way of creating statutes and the selection of their content. This includes both the procedure enshrined in constitutional statutes and informal politi-

68 See the oath of civil servants. Section 32, paragraph 2 of Act no. 234/2014 Coll., on Civil Service.

69 See the oath of MPs, senators, and the President of the Czech Republic. Section 23, paragraph 3 and Section 59, paragraph 2 of Constitutional Act no. 1/1993 Coll., the Constitution of the Czech Republic.

70 B. Friedman, The Will of the People. How Public Opinion Has Influenced the Supreme Court and Shaped the Meaning of the Constitution, New York 2009, pp. 367-368. If there is a social consensus on a particular matter, the legislator's inaction is a democratic dysfunction. J. Chafetz, The Phenomenology of gridlock, in: "Notre Dame Law Review" 2013, no. 5, p. 2082.

71 The Constitutional Court of the Czech Republic has declared the legislator to be inactive on the grounds of not responding to a professional discussion pointing out to inappropriateness of the existing legislation. See Ruling of the Constitutional Court of 27 June 2012, file no. II. ÚS 1534/10. Needs can be clearly articulated, for example, through the platforms of social movements J. Balkin. M., Principles, Practices and Social Movements, in: "University of Pennsylvania Law Review”2006, no. 4, p. 929. 
cal culture and the institutionalized practices of legislation which co-determine the resulting form of statutes. The process of law-making also includes the existence of the context of communication between the legislator, as the author of statutes on the one hand, and public authorities, as interpreters of statutes on the other hand. The context determines the meaning of legal texts and is thus an important element in the interpretation of statutes and as such it must be taken into account by the legislator. The context also includes, among other things, the conditions in society and their transformation. Which of all of the conditions are those to which the legislator must respond in order not to commit unconstitutional inactivity? It is defined by the possibilities and obligations of the individuals who are involved in the creation of statutes. The legislator must respond to those changes in the conditions that these individuals are able and obliged to reflect on.

If an unconstitutional gap in a statute or an unconstitutional statutory provision is found, the legislator is legally liable for such a defect in the legal order. The sanction in this respect is the abolition of that statutory provision or a ruling of the Constitutional Court that proclaims the existence of an unconstitutional gap or the unconstitutionality of the legislator's conduct. Whether such legal liability should include liability for compensation for legislative damage is subject to discussion. If, however, we decided to accept the legislator's liability for compensation for legislative damage, the question remains whether and where to draw the boundaries of such liability. Or in other words, in which cases the legislator (or the state) will be liable for damage. One of the ways to grasp the issue could be accepting the liability of the state for legislative damage in those cases where the legislator consciously interferes with the rights of individuals, i.e., when the result of the legislator's conduct is not only unconstitutional, but so is the legislator's conduct itself.

\section{Literature}

Alexy R., A Theory of Constitutional Rights, Oxford 2002.

Balkin J. M., Principles, Practices and Social Movements, "University of Pennsylvania Law Review" 2006, no. 4.

Bayme K., Parliamentary Democracy. Democratization, Destabilization, Reconsolidation, 1789-1999, Basingstoke 2000.

Bydlinski F., Grundzüge der juristischen Methodenlebre, Wien 2003.

Chafetz J., The Phenomenology of gridlock, "Notre Dame Law Review" 2013, no. 5.

Dicey A. V., Introduction To The Study Of The Law Of The Constitution, Indianapolis 1982.

Doerfler R. D., Who Cares How Congress Really Works?, "Duke Law Journal” 2017 no. 5.

Dworkin R., A Matter of Principlee, Cabmridge 1985.

Idem, Law's Empire, 3rd edition, London 1991.

Idem, Taking Rights Seriously.3rd edition, Cambridge 1977. 
Eco U., Lecotor in fabula, Prague 2010.

Idem, The role of the Reader. Explorations in the Semiotics of Texts, Bloomington 1984.

Ekins R., The nature of legislative intent, Oxford 2012.

Fairlie J., The Separation of Powers, "Michigan Law Review" 1923, no. 4.

Friedman B., The Will of the People. How Public Opinion Has Infuenced the Supreme Court and Shaped the Meaning of the Constitution, New York 2009.

Filip J., Ústavní právo České republiky, Brno 2011.

Fuller L. L., Morality of Law (revised edition), London 1969.

Gealfow J. A. Case Law and its Binding Effect in the System of Formal Sources of Law, "The Journal of the University of Latvia. Law" no. 11 (in print).

Gray J. C., The Nature and Sources of the Law, New York 1909.

Hapla M., Délba moci a nezávislost justice, Brno 2017.

Hobbes T., Leviathan, Cambridge 1996.

Holländer P., Ústavní změny: mezi neurózou a surrealismem in Ústava $\check{C} R$ - vznik, vývoj a perspektivy ed. P. Mlsna, Prague 2010.

Jellinek G., Allgemeine Staatslehre, Berlin 1929.

Langford C. L., The Living Constitution: Origins and Rhetorical Implications of the Constitution as Agent,"Communication Law Review" 2015, no. 1.

MacCormick N, Institutions of Law. An Essay in Legal Theory, Oxford 2007.

Manning J. F, The Absurdity Doctrine, "Harvard Law Review" 2003, no. 8.

McGarry J., Intention, Supremacy and Judicial Review, "The Theory and Practice of Legislation" 2013, no. 2.

Melzer F., Metodologie nalézáni práva. Úvod do právníargumentace, Prague 2009.

Nový Z., Evolutionary Interpretation of International Treaties, Den Haag 2017.

Patterson D. A Companion to Philosophy of Law and Legal Theory. 2nd edition, Singapore 2010.

Peczenik A., On Law and Reason. Dordrecht 2009.

Radburch G., Der Mensch im Recht: ausgewäblte Vorträge und Aufsätze über Grundfragen des Rechts. 3rd edition, Göttingen 1957.

Robinson J. A., The Relevance of a Contextualisation of the State-individual Relationship for Child Victims of Armed Conflict, "Potchfstroom Electronic Law Journal" 2012, no. 2.

Rüthers B., Dotváréeni práva soudci, "Soudce” 2003, no. 8.

Shapiro S. J., Legality. London 2011.

Stalnaker R. C., Context and Content, Oxford 1999.

Strauss D. A., Do We Have a Living Constitution?, "Drake Law Review" 2011, no. 4.

Waismann F., Verifiability, Logic and Language: First Series, ed. A. G. N. Flew, 1951.

Winberger O., Alternative Handlungstheorie, Wien-Köln-Weimar 1996.

Idem, Norm und Institution. Eine Einfübrung in die Theorie dews Rechts, Wien 1988. 
236 | Adam Mickiewicz University Law Review

SUMMARY

\section{Non-Originalism Differently: the Obligation of the Legislator to Respond to Changing Conditions}

The question that the paper seeks to answer is formulated through reflections on the issues of non-originalism. Non-originalism refers to an approach to the interpretation of the Constitution where the text of the Constitution adapts to new conditions without any formal change. This approach is applied by courts which, in the light of new circumstances, interpret the Constitution in a different way. The question is whether the same approach should also be applied by the legislator. Should it be the legislator who monitors whether the Constitution has changed in substance as a result of changes in society and that some existing statutes thus have become unconstitutional? The paper concludes that the legislator has an obligation to monitor and respond to such changes by amending or abolishing certain statutes or by adopting new ones. If the legislator fails to respond, then his behaviour - inaction - is unconstitutional. However, the paper does not claim that the legislator must respond to all the changes in society, but only to those that are significant and obvious. The legislator is understood as an institution, not as a member of the legislative body (based on the theory of the legislative intent). However, the institution of the legislator is a human creation and composed of individuals, and it is their knowledge that makes up the knowledge of the legislator. And it is precisely their possibilities that determine the boundaries of what the legislator should know. In this text, the creation of law is understood as communication between the legislator, who is the author of statutes, and public bodies, who interpret and apply them. As with any communication, context is what determines it. The legislator's obligations are derived from the content of the context, its function, and its essential position in communication.

Keywords: Legislator, Constitutional Court, Czech Republic, Changes, Society, Law, Statutes, Omission, Unconstitutional inactivity, Communication, Context, Content, Sources of Law, Law-making

Jana Koкešová, Department of Legal Theory, Masaryk University, Veveř́, 7061180 Brno Czech Republic, e-mail: jana.kokesova@post.cz. 